\title{
Seasonal variability in abundance, respiration and lipid composition of Arctic under-ice amphipods
}

\author{
Iris Werner ${ }^{1, *}$, Holger Auel $^{2}$ \\ ${ }^{1}$ Institute for Polar Ecology, Wischhofstraße 1-3, Gebäude 12, 24148 Kiel, Germany \\ ${ }^{2}$ Marine Zoology (FB2) University of Bremen, PO Box 330440, 28334 Bremen, Germany
}

\begin{abstract}
The Arctic under-ice amphipods Apherusa glacialis, Onisimus glacialis, $O$. nanseni and Gammarus wilkitzkii are autochthonous below the pack ice, i.e. they occur in this habitat during all seasons. In this study, seasonal dynamics in abundance were only evident in A. glacialis. Respiration rates did not differ significantly between summer and winter in any species, indicating that the under-ice habitat is a comparatively stable environment in terms of seasonal variations. The assessment of total lipids and fatty acid biomarkers revealed differences in feeding behaviour and overwintering strategy among the amphipod species. A. glacialis is strictly herbivorous, feeding on ice-algae at the underside of the ice during the productive season. The species overwinters in an active state, fuelled at least partly by internal lipid reserves stored during summer. O. glacialis switches from a predominantly herbivorous diet in summer to metazoan prey, including planktonic copepods, in winter, so that lipid catabolism is less important to winter survival. The congener $O$. nanseni relies on an opportunistic omnivorous diet throughout the year, with a higher proportion of metazoan prey during summer compared to O. glacialis. G. wilkitzkii is able to exploit a wide spectrum of food sources, from predominantly ice algae in summer to more ice fauna and planktonic copepods in winter. This species partly meets its energy requirements by using internal lipid reserves during winter.
\end{abstract}

KEY WORDS: Seasonal dynamics · Overwintering strategies - Cryo-pelagic coupling · Arctic foodweb · Apherusa glacialis · Onisimus glacialis · Onisimus nanseni · Gammarus wilkitzkii

\section{INTRODUCTION}

Polar regions are characterized by pronounced seasonal variations in light regimes, temperature, and primary production. Furthermore, polar marine ecosystems are strongly influenced by the seasonally changing sea-ice cover, which varies between 7 (summer) and 14 (winter) $\times 10^{6} \mathrm{~km}^{2}$ in the Arctic (Maykut 1985).

The underside of Arctic sea ice is a special habitat with particular abiotic and biotic conditions which vary seasonally (Werner \& Gradinger 2002). The macrofauna at the interface between ice and water comprises almost exclusively gammaridean amphipods; the most common species in perennial pack ice are Apherusa glacialis, Onisimus glacialis, O. nanseni and Gammarus wilkitzkii. As defined by Horner et al. (1992), these species are considered autochthonous, i.e. they occur in the under-ice habitat during all seasons and spend their entire life-cycle there (Lønne \& Gulliksen 1991a, Poltermann et al. 2000). These amphipods feed on ice-bound and under-ice flora and fauna, as well as on ice-bound detritus (Werner 1997, Poltermann 2001). Biomarkers like fatty acids have been used to identify different feeding types among these species (Scott et al. 1999). Metabolic rates, e.g. ingestion and respiration, of under-ice amphipods are generally low, due to their energy-saving lifestyle attached to the underside of the pack ice (Aarset 1991, Werner 1997, Werner et al. 2002).

Studies on seasonal dynamics of Arctic under-ice amphipods in off-shore pack ice have been mostly restricted to spring, summer and autumn (Lønne \& Gulliksen 1991a,b, Werner \& Gradinger 2002). Due to technical constraints, winter observations are scarce and have only provided qualitative data on the presence of several am- 
phipod species at the ice underside during this season (Melnikov 1997, Poltermann 1997).

As yet, it is not understood which energy sources enable under-ice amphipods to survive the winter season. Possible energy sources in winter are detritus or internal lipid reserves; alternatively, there may be a seasonal reduction of metabolic rates (Ikeda et al. 2000).

In order to close the gap in our understanding of their seasonal dynamics, the objectives of the present study were (1) to compare species richness and abundance of under-ice amphipods in the Fram Strait area during winter and summer, (2) to determine metabolic rates (as respiration rates) of the amphipods from different seasons in order to reveal possible seasonal acclimatizations, and (3) to elucidate potential overwintering strategies such as accumulation of storage lipids (by analysis of total lipids and lipid classes) or seasonal shifts in food preferences (by analysis of fatty acid biomarkers). The results of this seasonal comparison are discussed in the context of adaptation to the seasonally dynamic living conditions in the Arctic under-ice habitat.

\section{MATERIALS AND METHODS}

Sampling and processing of amphipods. Arctic underice amphipods of the species Apherusa glacialis (Han- sen), Onisimus glacialis (Sars), O. nanseni (Sars) and Gammarus wilkitzkii (Birula) were sampled during several expeditions with the RV 'Polarstern' to the northern Greenland Sea and Fram Strait during different seasons (Table 1). Temperature and salinity at the ice-water interface were measured with a WTW microprocessor conductivity meter LF 196 (accuracy: $\mathrm{T}=0.2^{\circ} \mathrm{C}, \mathrm{S}=0.2$ ) lowered through a core hole. Samples of the under-ice water were filtered on Whatmann GF/F glass fibre filters and analyzed fluorometrically for chlorophyll a after extraction in 90\% acetone (Evans et al. 1987). Amphipods were collected with different plankton nets (bongo, multinet, Nansen, rectangular midwater trawl), with ice corers, from baited traps and by means of an under-ice pumping system (Werner \& Martinez Arbizu 1999). Specimens used for respiration rates and lipid analysis came from the same collection sites. The 2 sympagic (=ice-associated) species of Onisimus occurring in the study area, O. glacialis and O. nanseni, which can be distinguished neither in situ nor alive, were identified from formaldehydefixed samples after Holmquist (1965).

Abundance of under-ice amphipods was estimated from recordings with a video camera lowered through a core hole to the underside of the ice. At each station during the expeditions ARK XVI/2, ARK XVIII/2 and ARK XIX/1b (Fig. 1), an area of ca. $80 \times 60 \mathrm{~cm}$ was

Table 1. Expeditions with RV 'Polarstern' to the northern Greenland Sea and Fram Strait (Arctic) with sampling of underice amphipods. Ranges of temperature, salinity and concentration of chlorophyll $a$ are given for the ice-water interface. L/W: length-weight relationship

\begin{tabular}{|c|c|c|c|c|c|c|c|c|}
\hline Expedition & Dates & Season & $\begin{array}{c}\text { Ice } \\
\text { cover } \\
(1 / 10)\end{array}$ & $\begin{array}{c}\text { Ice } \\
\text { thickness } \\
\text { (m) }\end{array}$ & $\begin{array}{l}\text { Temper- } \\
\text { ature } \\
\left({ }^{\circ} \mathrm{C}\right)\end{array}$ & Salinity & $\begin{array}{l}\text { Chloro- } \\
\text { phyll a } \\
\left(\mu g ~^{-1}\right)\end{array}$ & $\begin{array}{l}\text { Samples } \\
\text { used for }\end{array}$ \\
\hline \multicolumn{9}{|l|}{ ARK XIX/1b } \\
\hline Schauer \& Kattner (2004) & $\begin{array}{l}\text { Mar/Apr } \\
2003\end{array}$ & Winter & $7-10$ & $1.6-2.6$ & -1.8 to -1.2 & $33.8-34.4$ & $0.02-0.05$ & $\begin{array}{l}\text { L/W } \\
\text { Abundance } \\
\text { Respiration } \\
\text { Lipids }\end{array}$ \\
\hline \multicolumn{9}{|l|}{ ARK XIII/1 } \\
\hline Spindler et al. (1998) & $\begin{array}{l}\text { May/June } \\
1997\end{array}$ & Spring & $4-9$ & $1.6-3.5$ & -1.7 to -1.4 & $31.7-34.1$ & $0.10-0.32^{\mathrm{a}}$ & $\mathrm{L} / \mathrm{W}$ \\
\hline \multicolumn{9}{|l|}{ ARK X/1 } \\
\hline Fahrbach (1995) & $\begin{array}{c}\text { July/Aug } \\
1994\end{array}$ & Summer & $3-9$ & $2.2-3.5$ & -1.8 to -0.6 & $14.2-31.9$ & $0.30-2.65$ & $\begin{array}{l}\text { L/W } \\
\text { Lipids }\end{array}$ \\
\hline \multicolumn{9}{|l|}{ ARK XVI/2 } \\
\hline Krause \& Schauer (2001) & $\begin{array}{l}\text { July/Aug } \\
2000\end{array}$ & Summer & $1-10$ & $2.3-3.3$ & -1.8 to -0.3 & $29.7-33.3$ & $0.03-1.53$ & $\begin{array}{l}\text { L/W } \\
\text { Abundance } \\
\text { Respiration } \\
\text { Lipids }\end{array}$ \\
\hline \multicolumn{9}{|l|}{ ARK XVIII/2 } \\
\hline Jokat (2003) & $\begin{array}{c}\mathrm{Aug} / \mathrm{Oct} \\
2002\end{array}$ & Autumn & $1-9$ & $1.5-3.4$ & -1.8 to -1.6 & $30.5-32.5$ & $0.12-1.42$ & $\begin{array}{l}\text { L/W } \\
\text { Abundance } \\
\text { Respiration } \\
\text { Lipids }\end{array}$ \\
\hline \multicolumn{9}{|l|}{ ARK XI/2 } \\
\hline Krause (1996) & $\begin{array}{l}\text { Sept/Oct } \\
1995\end{array}$ & Autumn & $7-10$ & $1.6-3.3$ & -1.6 to -1.3 & $30.1-32.4$ & $0.03-0.33$ & $\begin{array}{l}\text { L/W } \\
\text { Lipids }\end{array}$ \\
\hline${ }^{a}$ From Obermüller (1999) & & & & & & & & \\
\hline
\end{tabular}




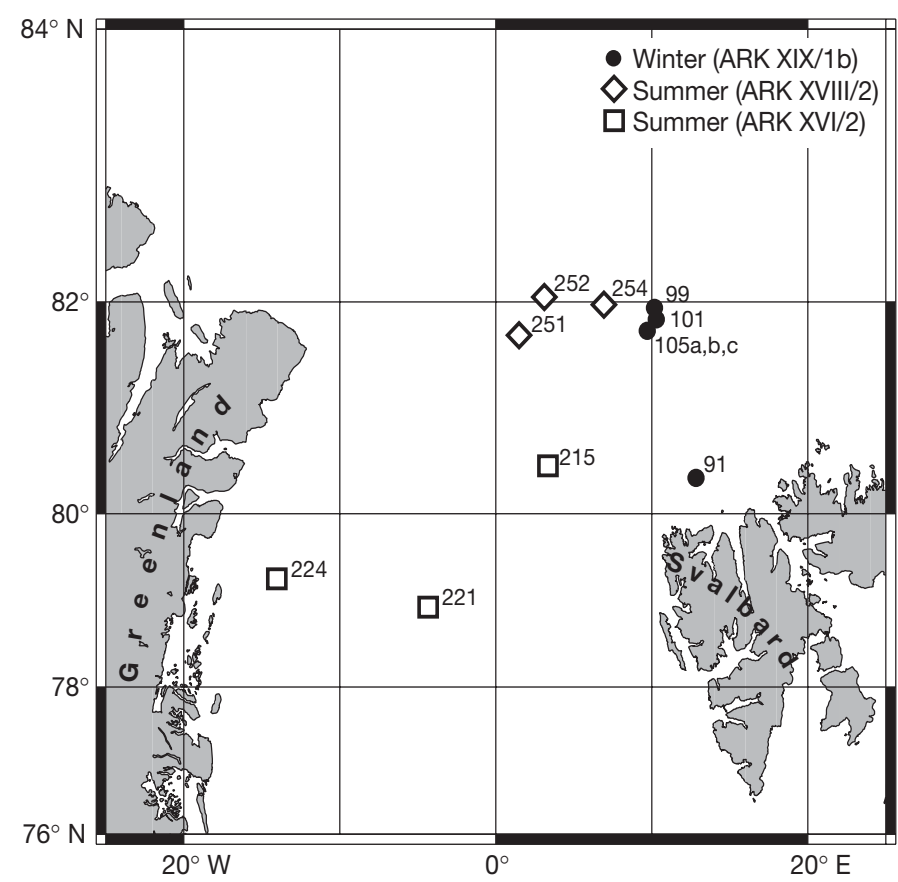

Fig. 1. Sampling sites during 3 RV 'Polarstern' expeditions in the Fram Strait area (Arctic). Station numbers are days of the year

observed for about $1 \mathrm{~h}$. Video recordings were evaluated using a computerized image analysis programme (BILD, on a NeXT workstation). For the determination of abundances, all visible amphipods were counted in a defined grid of $60 \times 40$ or $70 \times 50 \mathrm{~cm}$. A total of 15 randomly chosen images were analysed for each station and used for the calculation of the mean abundance per station (Werner \& Gradinger 2002).

Respiration measurements. In order to obtain standardized respiration rates not influenced by feeding and gut activities (Ikeda et al. 2000), amphipods were not fed for $24 \mathrm{~h}$ prior to the experiments during the expeditions ARK XVI/2, ARK XVIII/2 and ARK $\mathrm{XIX} / 1 \mathrm{~b}$. For the respiration measurements, test amphipods, either single or in groups of 2 to 5 animals, were placed gently in closed glass bottles (1270 or $625 \mathrm{ml}$ ) filled with filtered $(0.2 \mu \mathrm{m})$ and well oxygenated seawater ( $\mathrm{T}=0 \pm 1^{\circ} \mathrm{C}, \mathrm{S}=32$ to 34$)$. Control bottles without test animals were incubated concurrently (Omori \& Ikeda 1984). For Apherusa glacialis, 10 individuals were measured in winter and 14 in summer; for Onisimus spp. and Gammarus wilkitzkii, 11 individuals were measured in winter and 14 in summer. Immediately after the end of the incubation time in the dark (24 to $96 \mathrm{~h}$ ), oxygen concentrations were measured by Winkler titration (precision $0.05 \mathrm{ml} \mathrm{O}_{2} \mathrm{ml}^{-1}$ ).

Lipid analyses. Total lipids (TL) and lipid classes were measured in order to assess the potential use of storage lipids as an overwintering strategy (Hagen 2000). Fatty acid (FA) and fatty alcohol compositions were analyzed as biomarkers for certain food sources (Graeve et al. 1994, 1997). Based on the FA composition, the ratio of the FA isomers $18: 1(n-9)$ to $18: 1(n-7)$ was calculated. This quotient has been used as a relative index of carnivory in marine invertebrates (Graeve et al. 1997, Auel 1999, Falk-Petersen et al. 2000, Auel et al. 2002). Amphipods (from the expeditions ARK X/1, ARK XI/2, ARK XIII/1, ARK XVI/2, ARK XVIII/2 and ARK XIX/1b) were video-taped for image-based length measurements (to the nearest $0.1 \mathrm{~mm}$ ), and deep-frozen $\left(-80^{\circ} \mathrm{C}\right)$ for determination of freeze-dried dry mass (DM), which was determined after lyophilization for $48 \mathrm{~h}$. TL was extracted from amphipods from all expeditions (except for ARK XIII/1) with dichloromethane/methanol (2:1 per volume) essentially according to Folch et al. (1957) and Bligh \& Dyer (1959). TL content was measured gravimetrically (Hagen 2000). In addition, the lipid class composition of individuals sampled during ARK XVIII/2 and ARK XIX/1b was assessed. Lipid classes, i.e. wax esters (WE), triacylglycerols (TAG), sterols (STE), free fatty acids (FFA), and phospholipids/polar lipids (PL) were separated by thinlayer chromatography (TLC) on quartz rods coated with silica and quantified with a flame ionisation detector (FID, Iatroscan Mark IV) after Fraser et al. (1985). Analyses of FA and fatty alcohols were conducted with samples from the expeditions ARK XVI/2, ARK XVIII/2 and ARK XIX/1b. FA were converted to methyl esters and analysed together with the fatty alcohols by gas-liquid chromatography according to Kattner \& Fricke (1986). Methyl esters were prepared by transesterification with methanol containing $3 \%$ concentrated sulphuric acid at $80^{\circ} \mathrm{C}$ for $4 \mathrm{~h}$. FA and fatty alcohols were separated and quantified using a Hewlett-Packard gas chromatograph (HP 6890A) equipped with a DB-FFAP column of $30 \mathrm{~m}$ length and $0.25 \mathrm{~mm}$ diameter. Peaks were identified according to retention times in comparison to a fish oil and a copepod lipid standard of known compositions. The numbers of samples and individuals analyzed are given in Table 2 .

Statistical evaluation. Based on data from ice coverage during a cruise as well as from temperature, salinity and chlorophyll a concentrations at the ice underside (Table 1), abundance data and respiration measurements of amphipods were grouped into 2 seasonal data sets: winter (dense ice cover, freezing at the ice-water interface prevailing, low chl a) and summer (less dense ice cover, melting at the ice-water interface prevailing, moderate to high chl a). For the lipid data only, expeditions were grouped into summer, autumn and winter, in order to better demonstrate the gradual transitions of the lipid composition. 


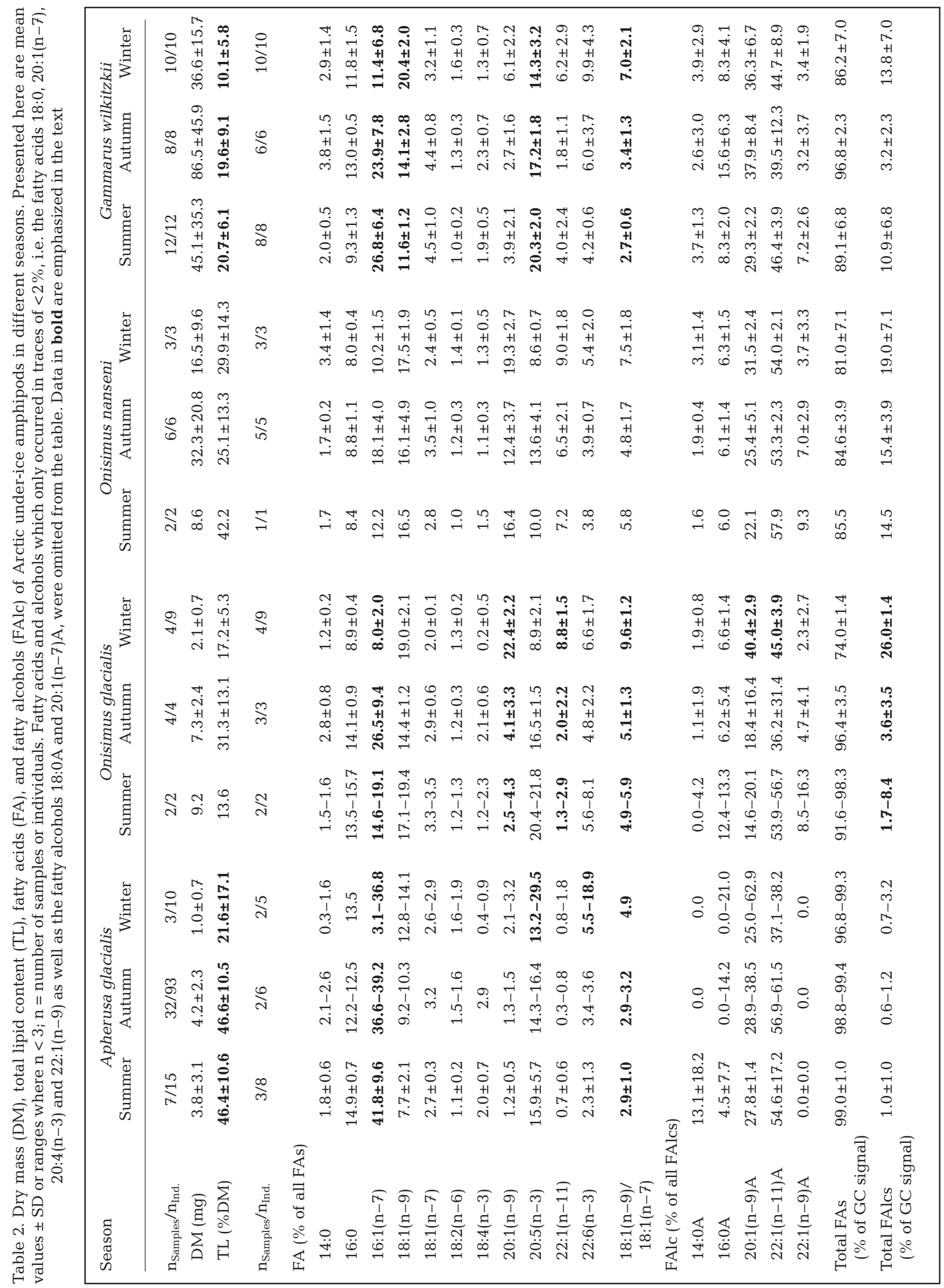


Normal distribution of data was tested by means of the Shapiro-Wilks test, and equality of variances with the Levene test. Data without normal distribution and with unequal variances (abundances) were tested with the median test, while data with normal distribution (specific respiration rates, TL) were tested with the $t$-test or an ANOVA (followed by the Tukey test) for differences between seasons. Differences were accepted as significant at $\mathrm{p} \leq 0.05$ (Lozán \& Kausch 1998).

In order to outline interspecific and seasonal changes in the fatty acid and fatty alcohol composition of the sympagic amphipods, a multivariate statistical analysis was conducted using the PRIMER software package (Clarke \& Warwick 1994). The similarities in the fatty acid and alcohol composition between each pair of samples were measured by the Bray-Curtis similarity coefficient (Bray \& Curtis 1957), and the results are presented as a multi-dimensional scaling plot (MDS, Kruskal \& Wish 1978). Within MDS, samples are ordered in a 2-dimensional plot in a way that best reflects their compositional similarities.

\section{RESULTS}

\section{Occurrence and abundance}

All 4 species of Arctic under-ice amphipods-Apherusa glacialis, Onisimus glacialis, O. nanseni and Gammarus wilkitzkii-were found during all seasons (winter, spring, summer, autumn) below pack ice in the study area. Length-weight relationships of A. glacialis and G. wilkitzkii, but not of Onisimus spp., showed slightly lower values of dry mass in winter than in summer (Fig. 2). In all species, the largest individuals were always found in summer. Median abundances of $A$. glacialis were significantly lower $\left(\chi^{2}=5.042, \mathrm{p}<0.05\right)$ in winter $\left(2.1\right.$ ind. $\left.\mathrm{m}^{-2}\right)$ than in summer $\left(6.5\right.$ ind. $\left.\mathrm{m}^{-2}\right)$. In contrast, median abundances of $G$. wilkitzkii did not differ significantly $\left(\chi^{2}=1.500, \mathrm{p}=0.2207\right)$ between winter (1.5 ind $\mathrm{m}^{-2}$ ) and summer (2.0 ind. $\mathrm{m}^{-2}$ ). However, maximum values and variabilities of abundances were much higher during summer than during winter in both species (Fig. 3). Abundances of Onisimus spp. were always low with a median $=0$.

\section{Respiration rates}

Mean specific respiration rates of Apherusa glacialis were very similar in winter $\left(14.0 \mathrm{ml} \mathrm{O}_{2} \mathrm{gDM}^{-1} \mathrm{~d}^{-1}\right)$ and in summer $\left(12.7 \mathrm{ml} \mathrm{O}_{2} \mathrm{gDM}^{-1} \mathrm{~d}^{-1}\right)$, but the measurements showed a comparatively high variability (Fig. 4). This species (smallest) showed the highest specific
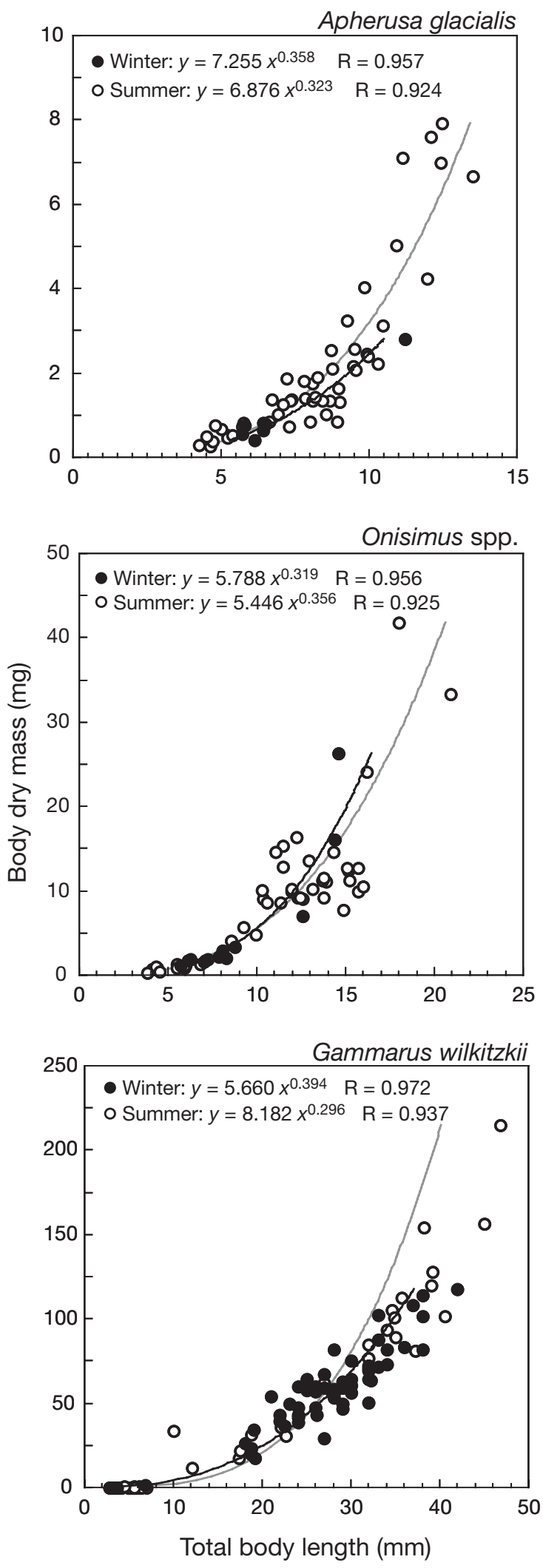

Fig. 2. Length-mass relationships of Arctic under-ice amphipods in winter and summer 


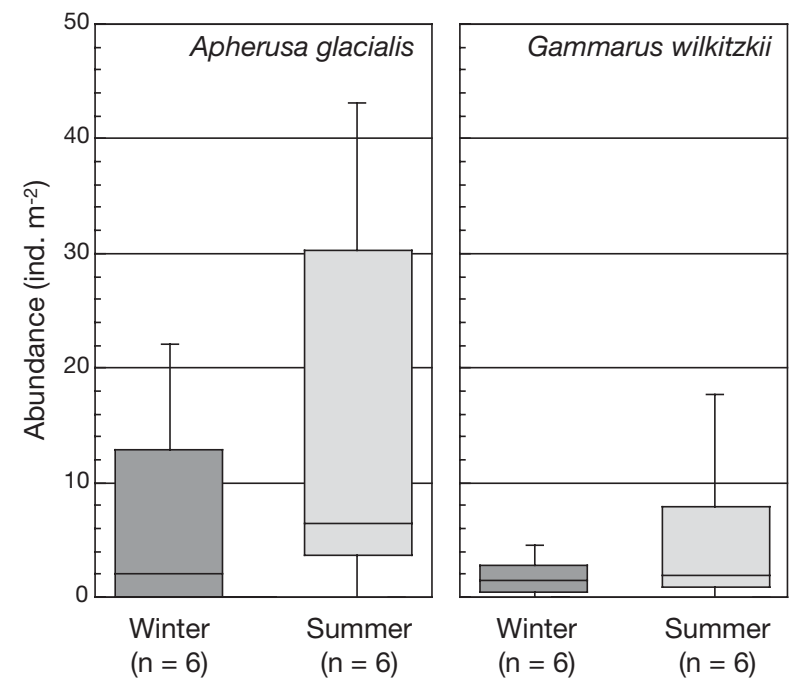

Fig. 3. Abundances of Arctic under-ice amphipods at the underside of pack ice in winter and summer. Ind. = individuals. Shown are the distributions of means per station (taken from 15 video images each). Line within box plot marks the median value; box shows 25 to $75 \%$ percentiles

respiration rates as compared to the other species. Respiration rates of Gammarus wilkitzkii did not differ between seasons (6.4 and $6.6 \mathrm{ml} \mathrm{O}_{2} \mathrm{gDM}^{-1} \mathrm{~d}^{-1}$, respectively). Mean specific respiration rates of Onisimus spp. were 6.3 and $4.9 \mathrm{ml} \mathrm{O}_{2} \mathrm{gDM}^{-1} \mathrm{~d}^{-1}$ in winter and summer, respectively. No significant difference between seasons was found in any species $(t=-0.185, \mathrm{p}=$ 0.859 for A. glacialis; $t=-1.021, \mathrm{p}=0.331$ for Onisimus spp.; $t=-0.288, \mathrm{p}=0.776$ for $G$. wilkitzkii).

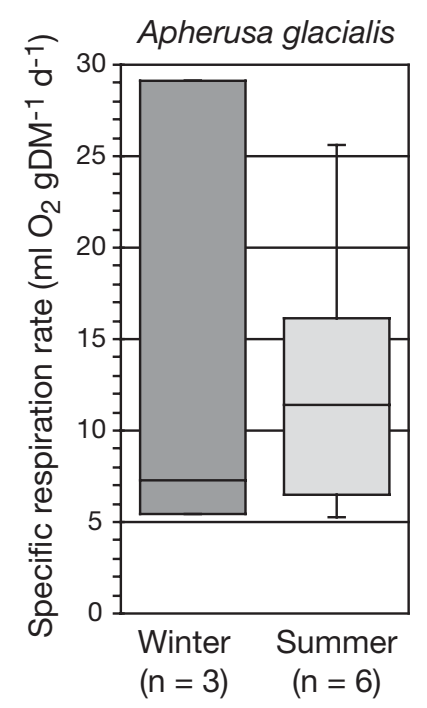

Onisimus spp.

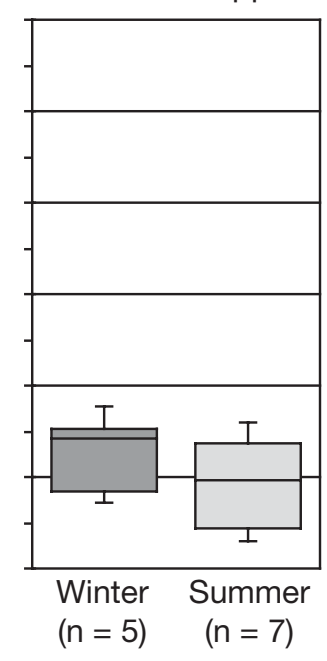

Gammarus wilkitzkii

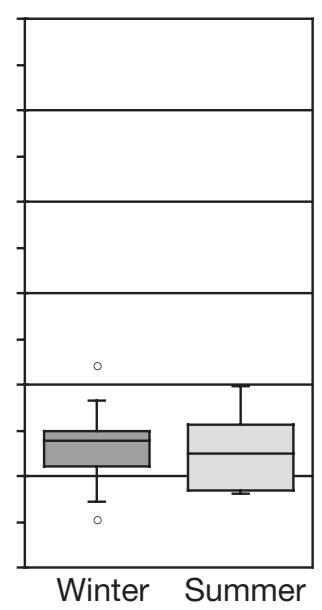

$(\mathrm{n}=11) \quad(\mathrm{n}=14)$
Fig. 4. Specific respiration rates of Arctic under-ice amphipods in winter and summer. $\mathrm{DM}=$ dry mass. Line within box plot marks the median value; box shows 25 to $75 \%$ percentiles. Single points represent outliers

\section{Lipid analyses}

In Apherusa glacialis mean TL contents strongly decreased significantly from $>46 \% \mathrm{DM}$ in summer and autumn to $21.6 \% \mathrm{DM}$ in late winter (ANOVA, p < 0.001) (Table 2, Fig. 5). Throughout the year, fatty acids represented 97 to $99 \%$ of the total GC (gas chromatography) signal strength, emphasising that fatty alcohols and therefore wax esters (WE) occurred only in traces. In some animals, the seasonal decrease in TL content was associated with a severe decline in the fatty acid 16:1(n-7), which usually represented around $40 \%$ of all fatty acids and was by far the most dominant fatty acid in summer and autumn (Table 2). In winter the percentage of 16:1(n-7) was very variable, with some individuals still containing 36.8\%, similar to summer data, while others were depleted to $3.1 \%$. Other important fatty acids in A. glacialis were $16: 0$ with 12 to $15 \%$ throughout the year, $18: 1(\mathrm{n}-9)$ with 8 to $14 \%, 20: 5(n-3)$ with generally 13 to $16 \%$ and $22: 6(n-3)$ with usually 2 to $6 \%$. In those winter individuals depleted in 16:1(n-7) and TL content, the relative fractions of the polyunsaturated fatty acids $20: 5(n-3)$ and 22:6(n-3) increased to 29.5 and $18.9 \%$, respectively. The ratio of the fatty acid isomers 18:1(n-9)/ 18:1(n-7) showed low values of approximately 3 in summer and autumn, and increased moderately to 4.9 in winter.

In Onisimus glacialis no significant seasonal trend in TL content could be identified. Mean lipid levels varied from 13.6\%DM in summer, to $31.3 \% \mathrm{DM}$ in autumn to $17.2 \%$ DM in winter (Table 2, Fig. 5). During summer and autumn, fatty alcohols only played a minor role with less than $8 \%$ of the total GC signal. However, during winter the fraction of fatty alcohols increased to $26 \%$. In summer and autumn the fatty acids 16:1(n-7), 20:5(n-3), 18:1(n-9) and 16:0 were the most dominant moieties, each contributing 15 to $27 \%$ of all fatty acids (Table 2). While 18:1(n-9) was also important in winter with $19 \%$, the diatom markers $16: 1(n-7)$ and 20:5(n-3) decreased to 8 to $9 \%$ in winter. In contrast, the longchain monounsaturated fatty acids 20:1(n-9) and 22:1(n-11), which usually comprised less than $4 \%$ in summer and autumn, strongly increased to 22 and $9 \%$, respectively, in winter. The ratio of 18:1(n-9)/18:1(n-7) nearly doubled from approximately 5 in summer and autumn to almost 10 in winter. Similar to the fatty acid composition, the fatty alcohol composition in winter 

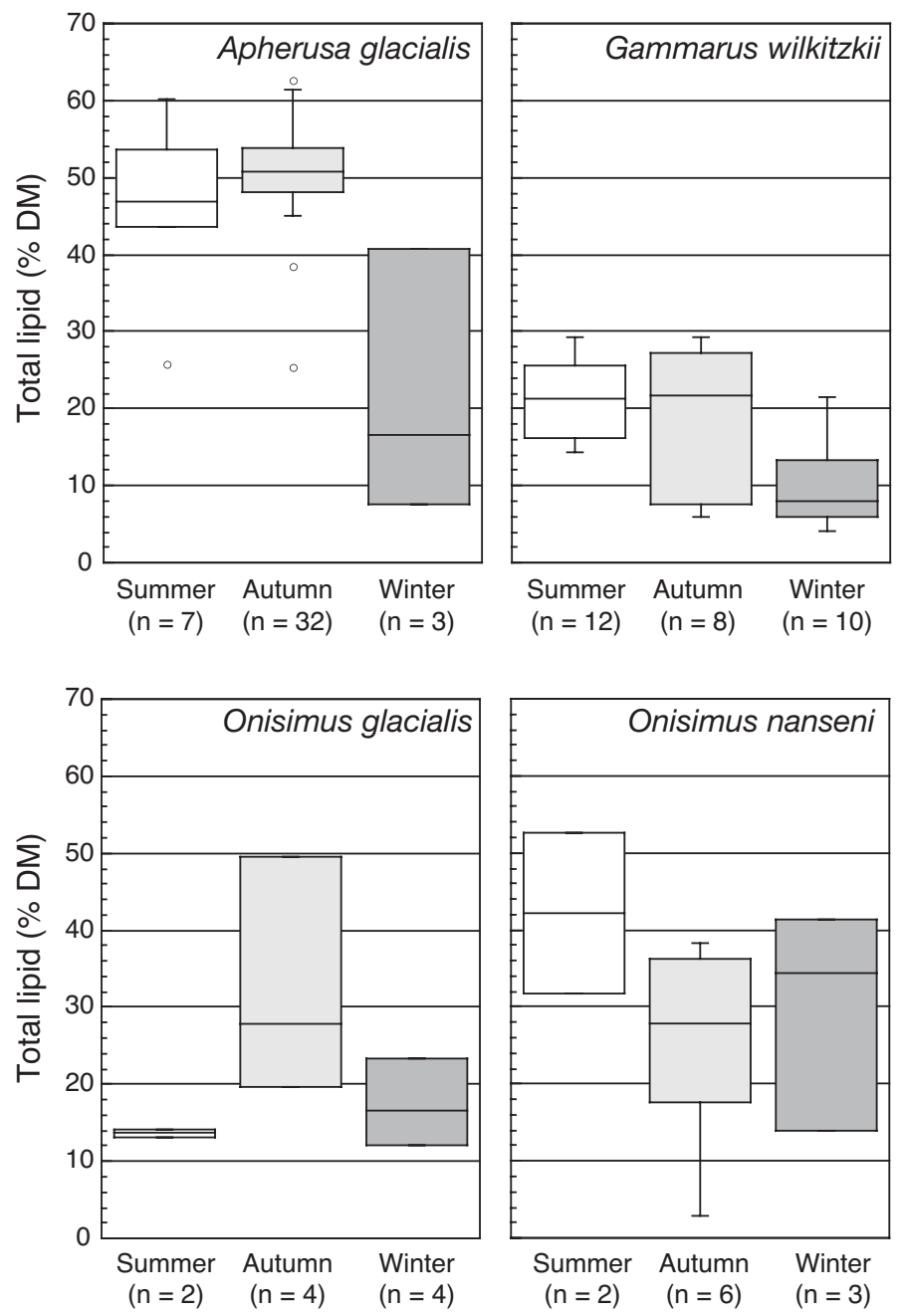

Fig. 5. Total lipid concentrations in Arctic under-ice amphipods in summer, autumn, and winter. DM = dry mass. Line within box plot marks the median value; box shows 25 to $75 \%$ percentiles. Single points represent outliers

was strongly dominated by the long-chain monounsaturated moieties 20:1(n-9) and 22:1(n-11), together comprising more than $85 \%$ of all fatty alcohols in winter.

In Onisimus nanseni, there was no significant seasonal change in TL levels (Fig. 5). Throughout the year, the most important fatty acids were the carnivory markers 18:1(n-9) and 20:1(n-9) as well as the diatom marker 16:1(n-7). All 3 moieties comprised 10 to $19 \%$ over the year (Table 2) and 20:5(n-3), 22:1(n-11) and 16:0 were present in moderate amounts of 7 to $14 \%$ each. The highest fractions of the carnivory markers 20:1(n-9), 22:1(n-11) and 18:1(n-9) were recorded in winter. Accordingly, the isomer ratio $18: 1(n-9) /$ 18:1(n-7) slightly increased from 5 to 6 in summer and autumn to 7.5 in winter. Fatty alcohols represented 15 to $19 \%$ of the total GC signal over the year with the long-chain monounsaturated moieties 20:1(n-9) and 22:1(n-11) contributing 22 to $32 \%$ and 53 to $58 \%$, respectively.

Gammarus wilkitzkii showed a significant decrease in mean TL content from 20.7\% DM in summer and $19.6 \% \mathrm{DM}$ in autumn to $10.1 \% \mathrm{DM}$ in winter (ANOVA, $\mathrm{p}<0.001$ ) (Table 2, Fig. 5). This decline was associated with a decrease in the diatom markers 16:1(n-7) and 20:5(n-3), which were the dominant fatty acids in summer and autumn with 17 to $27 \%$ of all fatty acids (Table 2). In winter these moieties only accounted for 11 and $14 \%$ of all fatty acids. In contrast, 18:1(n-9) almost doubled from $11.6 \%$ in summer to $14 \%$ in autumn to $20.4 \%$ in winter, and became the most important fatty acid of G. wilkitzkii in winter. Longchain monounsaturated forms, i.e. 20:1(n-9) and $22: 1(n-11)$, were present in low to moderate amounts from 2 to $6 \%$ with the highest values occurring in winter. The isomer ratio 18:1(n-9)/18:1(n-7) more than doubled from low values of approximately 3 in summer and autumn to 7 in winter. The fraction of fatty alcohols varied from $3 \%$ of total GC signal in autumn to $14 \%$ in winter. The long-chain monounsaturated fatty alcohols 22:1(n-11) and 20:1(n-9) dominated throughout the year with 40 to $46 \%$ and 29 to $38 \%$, respectively. In autumn, lipid class composition strongly depended on TL content. Individuals with high lipid levels of 18 to $25 \%$ DM contained high amounts of TAG (approximately $80 \%$ of TL), while PL played only a minor role with $7 \%$. In contrast, PL were much more important with 39 to $44 \%$ of TL in lean amphipods with lipid levels of only 6 and $7.5 \%$ DM. Here TAG only accounted for 36 to $47 \%$ of all lipids. Regardless of TL content, WE were present in moderate amounts of 6 to $13 \%$ in lean and fat individuals.

Fig. 6 shows the results of the MDS of amphipod samples based on their fatty acid and fatty alcohol composition. A stress coefficient of 0.11 emphasises the rather good representation of similarities in the 2-dimensional MDS plot. In 2 species, Onisimus glacialis and especially strong in Apherusa glacialis, samples from the different seasons are grouped in distinct clusters without overlap, underlining strong seasonal differences in lipid composition. In contrast, all samples of Onisimus nanseni are placed closed to each other with the single summer sample falling into the cluster of the autumn data. For Gammarus wilkitzkii there was a wide overlap in lipid composition from different seasons. However, the general trend from summer via autumn to winter samples (depicted in this MDS plot as translocation from lower left to upper right corner) is similar in A. glacialis, O. glacialis and, to a lesser extent, G. wilkitzkii. 


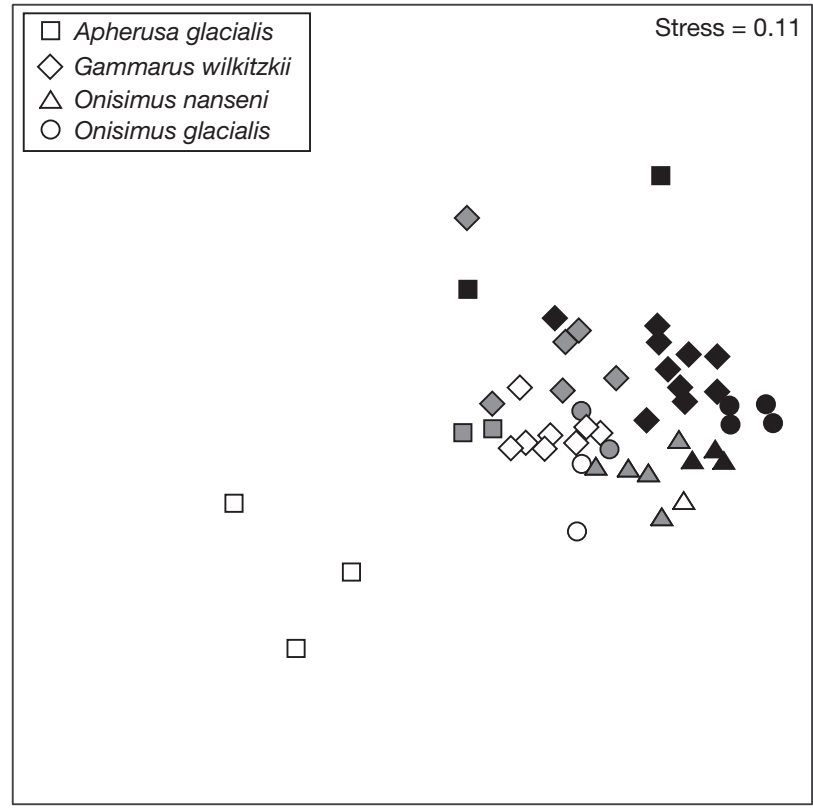

Fig. 6. Multi-dimensional scaling (MDS) plot of similarities in the fatty acid and alcohol composition of Arctic under-ice amphipods. Shades refer to different expedition cruises; white $=$ summer, grey $=$ autumn, black $=$ winter

\section{DISCUSSION}

\section{Seasons in the high-Arctic marine ecosystem}

The task of defining seasons, in particular biological seasons, in the high-Arctic marine ecosystem is not straightforward. The meaning of seasons here is somewhat different to those defined by the calendrical year. For instance, in March, when the calendrical spring starts in the northern hemisphere, ice cover is at a maximum in the entire Arctic (Maykut 1985), and algal biomass both in the ice and in the water directly beneath the ice is close to zero (Horner \& Schrader 1982, Thomas et al. 1995). On the other hand, in September, when the calendrical autumn starts, ice cover in the Arctic is at its minimum (Maykut 1985), and icealgal biomass in pack ice can reach maximum values (Werner \& Gradinger 2002). In the present study, we have mainly defined 2 seasons: winter, with very dense ice cover, freezing at the ice-water interface, and very little food available to the amphipods; and summer, with less dense ice cover, melting at the ice-water interface, and a moderate to high amount of food available to the amphipods. This simple distinction is based on the hypothesis that seasonal dynamics, if any, in the ecology of under-ice amphipods will be due to fluctuations in food availablity rather than to purely meteorological conditions. The fact that this seasonal comparison is based on several expeditions during different years represents, of course, a weak point for the data set; however, this is an inevitable compromise in highArctic off-shore research, which must be accepted until better opportunities for year-round studies arise. Furthermore, spatial effects, in particular of abundances, cannot be ruled out from the data set, but are considered to be small, because only multi-year ice from the Transpolar Drift System was sampled.

\section{Seasonal variations in abundance of under-ice amphipods}

All 4 species of under-ice amphipods have been found below pack ice in the Fram Strait area during all seasons, confirming the view that these species are truly autochthonous in this habitat. Quantitative data on their abundance during months earlier in the year than May have been lacking so far, mainly due to logistical constraints, but also due to an observed scarcity of amphipods during the winter months (Lønne \& Gulliksen 1991a). In the present study, abundances showed seasonal variations which were significant in the herbivorous species Apherusa glacialis. The winter values are among the lowest determined in multi-year pack ice (Hop et al. 2000, and references therein). It has been shown that abundances of this species are low or moderate in spring, reach their maximum in summer and decrease strongly towards autumn (Lønne \& Gulliksen 1991a, Werner \& Gradinger 2002). These seasonal dynamics are significantly related to ice-algal biomass and reflect the predominantly herbivorous feeding mode of this species (Werner 1997). It has been speculated that A. glacialis leaves the under-ice habitat to overwinter and reproduce in deeper waters (Melnikov \& Kulikov 1980), but significant evidence for this hypothesis is still lacking. Both egg-bearing females and females with juveniles in the marsurpium have been found in the under-ice habitat. Reproduction takes place during winter, and juveniles are released from March (Melnikov 1997, Poltermann 1997). A high mortality rate has been calculated for A. glacialis in its first year (Beuchel \& Lønne 2002), meaning that probably only part of the population survives the following winter. These losses may explain the lower abundances in winter (the present study) and spring (Werner \& Gradinger 2002). In summer the new recruits contribute to higher abundances.

Densities of Onisimus spp. and Gammarus wilkitzkii in winter were at the lower seasonal range (Hop et al. 2000, Werner \& Gradinger 2002). Although these seasonal differences were not significant, it seems that these species, which are more omnivorous than Apherusa glacialis and therefore do not depend so much on 
primary production (Poltermann 2001, Werner et al. 2002), lose part of their population during the winter. As in A. glacialis, reproduction in both Onisimus species and in $G$. wilkitzkii takes place mainly during the winter months, and juveniles are released from early spring on (Barnard 1959, Steele \& Steele 1975).

\section{Respiration rates in different seasons}

Respiration rates of all under-ice amphipods are comparatively low, probably due to their energy-saving lifestyle attached to the underside of the ice. The smallest species, Apherusa glacialis, exhibited the highest specific respiration rates, confirming the principally negative relationship between specific metabolism and body size within a metabolic group (Peters 1983). Specific respiration rates did not show any significant difference between winter and summer values in any of the amphipod species. This is well explained by the comparatively little seasonal variation in temperature at the ice-water interface of about $1.5^{\circ} \mathrm{C}$ at maximum. For Arctic benthic amphipods (Anonyx spp., Gammarus spp.) the same uniformity of respiration rates in summer and winter has been found, despite the seasonal temperature difference of up to $4^{\circ} \mathrm{C}$ in that habitat (Weslawski \& Opalinski 1997). However, some specimens of A. glacialis and Onisimus spp. showed higher respiration rates in winter than in summer. A potential reason for this is that these amphipods have to cover larger areas in winter in search of limited food resources, such as algal detritus. In addition, autochthonous under-ice amphipods cannot find refuge from winter-active predators like Gammarus wilkitzkii and polar cod Boreogadus saida in their habitat. Thus, reducing their metabolic activity in order to save energy may not be an option for these amphipod species during winter. This view is supported by video observations during the present study, which showed the same level of activity and mobility in amphipods throughout the year. Thus, the major question is, which food and energy sources do under-ice amphipods base their overwintering below the pack ice on.

\section{Food, feeding and overwintering strategies}

The analysis of seasonal trends in lipid content and composition revealed distinct differences in the feeding behaviour and overwintering strategies of the 4 sympatric under-ice amphipod species. For Apherusa glacialis, Onisimus nanseni and Gammarus wilkitzkii, the dry mass of individuals included in the lipid assay varied considerably, but the size ranges of samples from the different seasons generally showed a wide overlap, thus permitting seasonal comparisons. In contrast, the individual dry mass of $O$. glacialis decreased from $>9 \mathrm{mg}$ in summer, via $7.3 \mathrm{mg}$ in autumn to $2.1 \mathrm{mg}$ in winter, indicating that seasonal trends may be influenced by size-related effects.

Apherusa glacialis is a herbivorous species which feeds extensively on ice algae, predominantly diatoms, at the underside of the sea ice (Werner 1997, Scott et al. 1999). In our summer and autumn data, this is reflected in very high concentrations of the 16:1(n-7) fatty acid, which is a typical component of diatoms (Graeve et al. 1994, Falk-Petersen et al. 1998), and low values for the isomer ratio $18: 1(n-9) /$ 18:1(n-7), which has been proposed as a relative index of carnivory (Graeve et al. 1997, Falk-Petersen et al. 2000, Auel et al. 2002). In winter, when ice algae are scarce, A. glacialis seems to rely at least partly on the catabolism of stored lipids as an energy source. This is evident from the strong decline in TL content from autumn to late winter. In winter some individuals continued to have high amounts of 16:1(n-7), similar to summer, while in others it was severely depleted. The comparatively low number of winter samples, especially of this species, may limit the validity of the conclusions drawn. However, the variability may also be explained by a more patchy distribution of food sources, such as algal detritus clumps, during winter. Fresh ice algae, such as diatoms and chrysophytes, were also present in the bottom of the winter ice, albeit in very low numbers (J. Ikävalko pers. comm.). The dominance of the polyunsaturated fatty acids 20:5(n-3) and 22:6(n-3) in lean individuals is related to the fact that polyunsaturated fatty acids are major components of biomembranes and these structural lipids prevail when storage lipids are depleted.

Onisimus glacialis contained biomarker fatty acids for diatoms, i.e. 16:1(n-7) and 20:5(n-3), in high concentrations only in summer and autumn, but accumulated high amounts of indicators for a carnivorous diet including calanid copepods during winter, such as the fatty acid 18:1(n-9) and the long-chain monounsaturated fatty acids and alcohols 20:1(n-9) and 22:1(n-11). Correspondingly, the carnivory index 18:1(n-9)/18:1 (n-7) nearly doubled from summer (4.9 to 5.9$)$ to winter $(9.6 \pm 1.2$, Table 2$)$. This amphipod species is generally referred to as omnivorous (Scott et al. 1999, Poltermann 2001). Our results reveal that a switch in feeding behaviour occurs, from ice algae in summer to metazoan prey in winter. Since calanid copepods, e.g. Calanus spp., are also present in the under-ice habitat during winter (Horner \& Murphy 1985, Werner 2004), O. glacialis finds sufficient food resources, meaning that there is no significant reduction in TL content at this time of the year. 
Onisimus nanseni showed a lipid composition typical of omnivorous feeding with a combination of metazoan markers (18:1[n-9], 20:1[n-9]) and diatom indicators (16:1[n-7]) throughout the year. Highest concentrations of metazoan markers and a slightly increased index of carnivory $(18: 1[n-9] / 18: 1[n-7])$ occurred during winter, but seasonal changes in lipid composition and feeding behaviour of $O$. nanseni were less pronounced than those of the congener O. glacialis. $O$. nanseni seems to rely on an opportunistic feeding mode with an omnivorous diet (Scott et al. 1999). Although reduced feeding activity has been observed in this species in winter (Poltermann 2001), this amphipod follows a 'business as usual' strategy without specific adaptations for overwintering, but with an increased proportion of metazoan prey and detritus as an additional food source. Moderate levels of long-chain monounsaturated fatty acids and alcohols throughout the year indicate that calanid copepods represent important prey items during all seasons. Correspondingly, we found O. nanseni to be the only Arctic underice amphipod with moderate levels of fatty alcohols and, hence, WE as storage lipids throughout the year. This is in contrast to observations by Scott et al. (1999), who recorded significant amounts of WE only in $O$. glacialis.

Gammarus wilkitzkii is generally considered as omnivorous to carnivorous (Werner 1997, Poltermann 2001). Studies on its fatty acid composition in the Barents Sea (Scott et al. 1999), as well as feeding experiments with individuals from the Greenland Sea (Werner et al. 2002) revealed that calanid copepods represent a major dietary component of $G$. wilkitzkii during summer. Surprisingly, and in contrast to most published results, summer individuals sampled in the present study contained high amounts $(>20 \%)$ of the diatom markers 16:1(n-7) and 20:5(n-3), while the typical indicators for calanid copepods as prey, i.e. 20:1(n-9) and 22:1(n-11) were only present in low levels of $4 \%$. Thus, summer individuals of G. wilkitzkii were predominantly herbivorous in the present study. Correspondingly, the carnivory index 18:1(n-9)/18:1(n-7) showed very low values of less than 3 , comparable to those of the herbivorous Apherusa glacialis. During winter, lower amounts of 16:1(n-7), slightly elevated concentrations of calanid markers and an increased carnivory index suggest a change in diet composition from primarily ice algae in summer to metazoan prey in winter, similar to the switch in feeding behaviour of Onisimus glacialis. However, even in winter, calanid markers and the carnivory index of G. wilkitzkii were substantially lower than those of $O$. glacialis and, in contrast to O. glacialis, the TL content of G. wilkitzkii decreased in winter to less than half of the summer value. Thus, the change to predatory feeding during winter is apparently less profitable for G. wilkitzkii, and a considerable proportion of its energetic needs has to be covered by internal lipid reserves. The contrasting results with regard to the feeding behaviour, diet composition and trophic level of G. wilkitzkii between the present study and published data (Scott et al. 1999, Werner et al. 2002) indicate strong spatial and temporal variability. G. wilkitzkii has apparently developed a highly flexible and opportunistic strategy to cope with changing feeding conditions in the variable under-ice habitat. This species is able to exploit a wide spectrum of different, locally abundant food sources ranging from ice algae to detritus and from ice fauna to predatory feeding on other under-ice amphipods and planktonic copepods (Werner 1997, Scott et al. 1999, Poltermann 2001, Werner et al. 2002).

Seasonal changes in feeding behaviour also become evident in the MDS plot (Fig. 6) based on similarities in the fatty acid and fatty alcohol composition of the different amphipod species. While MDS plots generally do not explain the causal relationships of the observed similarity patterns, the parallel seasonal trends in 3 species Apherusa glacialis, Onisimus glacialis and Gammarus wilkitzkii indicate similar seasonal changes in feeding strategy and diet composition, presumably from a more herbivorous diet in summer to a predominantly omnivorous or carnivorous nutrition together with catabolism of stored lipids in autumn and winter. This response is more pronounced in the strictly herbivorous A. glacialis, which is more affected by the seasonally limited food supply, than in the generally more omnivorous O. glacialis and the omnivorous to carnivorous G. wilkitzki.

Interestingly, all amphipod species accumulated WE only when feeding on WE rich prey such as calanid copepods. Onisimus glacialis only contained WE during winter, while $O$. nanseni and to a lesser extent Gammarus wilkitzkii had moderate levels of WE in all seasons. These results may indicate that all 3 species have developed the ability to directly absorb and incorporate dietary $\mathrm{WE}$, without prior digestion to fatty acid and alcohol components. Otherwise, it remains uncertain why these amphipods should resynthesize WE from ingested fatty acid and alcohol precursors, despite generally preferring TAG as storage lipids.

\section{CONCLUSIONS}

(1) All 4 dominant species of Arctic under-ice amphipods-Apherusa glacialis, Onisimus glacialis, O. nanseni and Gammarus wilkitzkii-are present in the under-ice habitat during all seasons, including winter, thus confirming their autochthonous status in this habitat. Seasonal variabilities in abundance are evi- 
dent for the herbivorous species A. glacialis, but not for the other more omnivorous species, indicating that the varying food supply is the major seasonal factor for these sympagic species. (2) Metabolic rates, activity, and thus energy requirements of all 4 species are strikingly similar during summer and winter. This characterizes the under-ice habitat as a comparatively stable environment in terms of temperature regime throughout the seasons, which does not require seasonal metabolic acclimatizations. (3) Feeding behaviour and food preferences during different seasons are different in all 4 species of under-ice amphipods, demonstrating an effective development of species-specific overwintering strategies in this extreme environment.

Acknowledgements. We thank captains, crews, chief scientists and many colleagues on board the RV 'Polarstern' for their constant support during the expeditions. In particular, the help of several members of the sea-ice working groups in the field is greatly acknowledged. A. Schetz conducted most of the chl a measurements, P. Wencke ran the machinery for almost all lipid analyses, and R. Kiko helped with many of the length measurements. The manuscript benefitted substantially from the constructive comments made by 2 anonymous referees.

\section{LITERATURE CITED}

Aarset AV (1991) The ecophysiology of under-ice fauna. Polar Res 10:309-324

Auel H (1999) The ecology of Arctic deep-sea copepods (Euchaetidae and Aetideidae). Aspects of their distribution, trophodynamics and effect on the carbon flux. Ber Polarforsch 319:1-97

Auel H, Harjes M, da Rocha R, Stübing D, Hagen W (2002) Lipid biomarkers indicate different ecological niches and trophic relationships of the Arctic hyperiid amphipods Themisto abyssorum and T. libellula. Polar Biol 25: 374-383

Barnard JL (1959) Epipelagic and under-ice amphipoda of the central Arctic basin. Geophys Res 1:115-129

Beuchel F, Lønne OJ (2002) Population dynamics of the sympagic amphipods Gammarus wilkitzkii and Apherusa glacialis in sea ice north of Svalbard. Polar Biol 25: 241-250

Bligh EG, Dyer WJ (1959) A rapid method of total lipid extraction and purification. Can J Biochem Physiol 37:911-917

Bray JR, Curtis JT (1957) An ordination of the upland forest of Southern Wisconsin. Ecol Monogr 27:225-349

Clarke KR, Warwick RM (1994) Changes in marine communities: an approach to statistical analysis and interpretation. Plymouth Marine Laboratory, NERC, Plymouth

Evans CA, O'Reilly E, Thomas JP (1987) A handbook for the measurement of chlorophyll $a$ and primary production. BIOMASS Sci Ser 8, Texas A\&M University, College Station, TX

Fahrbach E (1995) The expedition ARKTIS X/1 of the research vessel 'Polarstern' in 1994. Ber Polarforsch 181: $1-79$

Falk-Petersen S, Hagen W, Kattner G, Clarke A, Sargent J (2000) Lipids, trophic relationships, and biodiversity in Arctic and Antarctic krill. Can J Fish Aquat Sci 57(Suppl 3):178-191
Falk-Petersen S, Sargent JR, Henderson J, Hegseth EN, Hop H, Okolodkov YB (1998) Lipids and fatty acids in ice algae and phytoplankton from the Marginal Ice Zone in the Barents Sea. Polar Biol 20:41-47

Folch J, Lees M, Sloane-Stanley GH (1957) A simple method for the isolation and purification of total lipids from animal tissues. J Biol Chem 226:497-509

Fraser AJ, Tocher DR, Sargent JR (1985) Thin-layer chromatography-flame ionization detection and the quantitation of marine neutral lipids and phospholipids. J Exp Mar Biol Ecol 88:91-100

Graeve M, Kattner G, Hagen W (1994) Diet-induced changes in the fatty acid composition of Arctic herbivorous copepods: experimental evidence of trophic markers. J Exp Mar Biol Ecol 182:97-110

Graeve M, Kattner G, Piepenburg D (1997) Lipids in Arctic benthos: does the fatty acid and alcohol composition reflect feeding and trophic interactions? Polar Biol 18: $53-61$

Hagen W (2000) Lipids. In: Harris RP, Wiebe PH, Lenz J, Skjoldal HR, Huntley M (eds) ICES zooplankton methodology manual. Academic Press, San Diego, p 113-119

Holmquist C (1965) The amphipod genus Pseudalibrotus. Z Zool Syst Evolutionsforsch 3:19-46

Hop H, Poltermann M, Lønne OL, Falk-Petersen S, Korsnes R, Budgell WP (2000) Ice amphipod distribution relative to ice density and under-ice topography in the northern Barents Sea. Polar Biol 23:357-367

Horner RA, Murphy D (1985) Species composition and abundance of zooplankton in the nearshore Beaufort Sea in winter-spring. Arctic 38:201-209

Horner RA, Schrader GC (1982) Relative contributions of ice algae, phytoplankton, and benthic microalgae to primary production in nearshore regions of the Beaufort Sea. Arctic 35:485-503

Horner R, Ackley SF, Dieckmann GS, Gulliksen B and 6 others (1992) Ecology of sea ice biota. 1. Habitat, terminology, and methodology. Polar Biol 12:417-427

Ikeda T, Torres JJ, Hernández-León S, Geiger SP (2000) Metabolism. In: Harris RP, Wiebe PH, Lenz J, Skoldal HR, Huntley M (eds) ICES zooplankton methodology manual. Academic Press, San Diego, p 455-532

Jokat W (2003) The expedition ARKTIS XVIII/2 of RV 'Polarstern' in 2002. Contributions of the participants. Ber Polarforsch 449:1-63

Kattner G, Fricke HSG (1986) Simple gas-liquid chromatographic method for simultaneous determination of fatty acids and alcohols in wax esters of marine organisms. J Chromatogr 361:313-318

Krause G (1996) The expedition ARKTIS-XI/2 of RV 'Polarstern' in 1995. Ber Polarforsch 197:1-65

Krause G, Schauer U (2001) The expeditions ARKTIS XVI/1 and ARKTIS XVI/2 of the RV 'Polarstern' in 2000. Ber Polarforsch 389:48-108

Kruskal JB, Wish M (1978) Multidimensional scaling. Sage Publishing, Beverly Hills, CA

Lønne OJ, Gulliksen B (1991a) On the distribution of sympagic macro-fauna in the seasonally ice covered Barents Sea. Polar Biol 11:457-469

Lønne OJ, Gulliksen B (1991b) Sympagic macro-fauna from multiyear sea-ice near Svalbard. Polar Biol 11:471-477

Lozán Jl, Kausch H (1998) Angewandte Statistik für Naturwissenschaftler. Parey Buchverlag, Berlin

Maykut GA (1985) The ice environment. In: Horner RA (ed) Sea ice biota. CRC Press, Boca Raton, FL, p 21-82

Melnikov IA (1997) The Arctic sea ice ecosystem. Gordon \& Breach Science Publishers, Amsterdam 
Melnikov IA, Kulikov AS (1980) Cryopelagic fauna of the Central Arctic Basin. In: Vinogradov ME, Melnikov IA (eds) Biology of the Central Arctic Basin. Nauka, Moscow, p 97-111

Obermüller B (1999) Charakterisierung arktischer Mesozooplanktongemeinschaften während einer Winter-/Frühjahrs-Übergangsperiode. Diplomathesis, Universität Kiel

Omori M, Ikeda T (1984) Methods in marine zooplankton ecology. John Wiley \& Sons, New York

Peters RH (1983) The ecological implications of body size. Cambridge University Press, Cambridge

Poltermann M (1997) Biology and ecology of cryopelagic amphipods from Arctic sea ice. Ber Polarforsch 225:1-170

Poltermann M (2001) Arctic sea ice as a feeding ground for amphipods-food sources and strategies. Polar Biol 24: 89-96

Poltermann M, Hop H, Falk-Petersen S (2000) Life under Arctic sea ice-reproduction strategies of two sympagic (iceassociated) amphipod species, Gammarus wilkitzkii and Apherusa glacialis. Mar Biol 136:913-920

Schauer U, Kattner G (2004) The Expedition ARKTIS XIX/1 a, $\mathrm{b}$ and XIX/2 of the RV 'Polarstern' in 2003. Ber Polarforsch 481:1-190

Scott CL, Falk-Petersen S, Sargent JR, Hop H, Lønne OJ, Poltermann M (1999) Lipids and trophic interactions of ice fauna and pelagic zooplankton in the marginal ice zone of the Barents Sea. Polar Biol 21:65-70

Spindler M, Hagen W, Stübing D (1998). Scientific cruise report of the Arctic expedition ARK-XIII/1 of RV 'Polar-

Editorial responsibility: Otto Kinne (Editor-in-Chief), Oldendorf/Luhe, Germany stern' in 1997. Ber Polarforsch 296:1-65

Steele DH, Steele VJ (1975) The biology of Gammarus (Crustacea, Amphipoda) in the northwestern Atlantic. IX. Gammarus wilkitzkii Birula, Gammarus stoerensis Reid, and Gammarus mucronatus Say. Can J Zool 53:1105-1109

Thomas DN, Lara RL, Eicken H, Kattner G, Skoog A (1995) Dissolved organic matter in Arctic multi-year sea ice during winter: major components and relationship to ice characteristics. Polar Biol 15:477-483

Werner I (1997) Grazing of Arctic under-ice amphipods on sea-ice algae. Mar Ecol Prog Ser 160:93-99

Werner I (2004) Living conditions, abundance and biomass of under-ice fauna in the Storfjord area (western Barents Sea, Arctic) in late winter (March 2003). Polar Biol DOI 10.1007/s00300-004-0678-1

Werner I, Gradinger R (2002) Under-ice amphipods in the Greenland Sea and Fram Strait (Arctic): environmental controls and seasonal patterns below the pack ice. Mar Biol 140:317-326

Werner I, Martinez Arbizu P (1999) The sub-ice fauna of the Laptev Sea and the adjacent Arctic Ocean in summer 1995. Polar Biol 21:71-79

Werner I, Auel H, Friedrich C (2002) Carnivorous feeding and respiration of the Arctic under-ice amphipod Gammarus wilkitzkii. Polar Biol 25:523-530

Weslawski JM, Opalinski KW (1997) Winter and summer metabolic rates of Arctic amphipods. Preliminary results. In: Glowacki P (ed) Polish polar studies. 24th Polar Symposium, Polish Academy of Sciences, Warszawa, p 307-317

Submitted: July 22, 2004; Accepted: November 25, 2004 Proofs received from author(s): April 18, 2005 